\title{
Year-round chemical aerosol records in continental Antarctica obtained by automatic samplings
}

ROLF WELLER ${ }^{* 1}$ and DIETMAR WAGENBACH ${ }^{2},{ }^{1}$ Alfred Wegener Institute for Polar and Marine Research, Am Handelshafen 12, 27570 Bremerhaven, Germany, ${ }^{2}$ Institut für Umweltphysik, University Heidelberg, Im Neuenheimer Feld 229, D-69120 Heidelberg, Germany

\footnotetext{
* Correponding author.

e-mail: Rolf.Weller@awi.de
} 


\begin{abstract}
Aimed at year-round recording of the chemical aerosol composition in central Antarctica, an unattended operating aerosol sampler was successfully deployed at the EPICA deep drilling site in Dronning Maud Land (Kohnen Station). Analyses of teflon/nylon filter packs consecutively collected over bi-weekly intervals during the February 2003 to December 2005 period allowed to evaluate seasonal concentration variations of methane sulfonate (MS), $\mathrm{Cl}^{-}, \mathrm{NO}_{3}^{-}$, non-sea salt (nss-) $\mathrm{SO}_{4}{ }^{2-}$, and $\mathrm{Na}^{+}$, while $\mathrm{NH}_{4}{ }^{+}$and mineral dust related ion results remained below detection limits. For MS and nss- $\mathrm{SO}_{4}{ }^{2-}$ distinct late summer maxima around $44 \mathrm{ng} \mathrm{m}^{-3}$ and $200 \mathrm{ng} \mathrm{m}^{-3}$, respectively, were found, while (total) $\mathrm{NO}_{3}^{-}$showed a broad November maximum of about $52 \mathrm{ng} \mathrm{m}^{-3}$. In contrast, the highest concentrations of $\mathrm{Na}^{+}$with peak values of up to $160 \mathrm{ng} \mathrm{m}^{-3}$ were observed during the winter half year. The seasonality of these species broadly coincided with long term observations at the coastal Neumayer Station, including surprisingly comparable $\mathrm{NO}_{3}{ }^{-}$levels. However, the biogenic sulfur and sea salt concentrations were lower at Kohnen by typically a factor of 2-3 and 10, respectively. The arrival of sea ice derived sea salt particles at Kohnen could not clearly be detected, since even during midwinter the nss- $\mathrm{SO}_{4}{ }^{2-}$ to $\mathrm{Na}^{+}$ratio was generally too high to unambiguously identify a sulfur depleted sea salt $\mathrm{SO}_{4}{ }^{2-}$ fraction.
\end{abstract}




\section{Introduction}

In addressing the coupling between climate and biogeochemical cycles, Antarctic ice cores provide an unique archive of climate and environmental proxies. Basically, these ice cores allow to infer past changes over several climatic cycles of local temperature, circulation patterns and of various atmospheric constituents in adequate temporal resolution (e.g. Legrand and Mayewski, 1997; Wolff et al., 2006; EPICA Community Members, 2006). However, particularly in view of aerosol related species, the detailed interpretation of their continental Antarctic ice cores records remained partly ambiguous in terms of net atmospheric changes (Wolff et al., 2003; Ruth et al., 2004; Hastings et al., 2005; Jonsell et al., 2005; Bigler et al., 2006). In order to reduce this deficit, at least for Holocene climate conditions, year round aerosol (and associated trace gas) observations are needed from the relevant ice core-drilling site. First of all, such atmospheric records should comprise the set of ion species, commonly recorded in ice cores under investigation, which cover sea salt, mineral dust, biogenic and volcanic sulfur components as well as nitrate and ammonium. While detailed long-term records of chemical aerosol species are available from coastal Antarctic stations as Neumayer (Wagenbach, 1996) and Durmont d'Urville (Jourdain and Legrand, 2001), only very scattered atmospheric observations are obtained so far at central Antarctic positions (Bodhaine et al., 1986). Since most of these inland records were restricted to austral summer with only few ion data obtained during polar night (Tuncel et al., 1989; de Mora et al., 1997; Harder et al., 2000; Arimoto et al., 2001 and 2004; Udisti et al., 2004; Piel et al., 2006), representative seasonal cycles of ionic aerosol compounds in the central Antarctic boundary layer remained virtually unknown. However, in elucidating to what extend the glacio-chemical signals may be related to the respective atmospheric aerosol changes, seasonality matters for several reasons. First, since ionic firn impurities originate from dry and wet deposition of aerosols and water-soluble trace gases, their mean firn levels (and the overall wet deposited fraction) may be governed by 
the interference of the seasonal cycles of net snow accumulation and atmospheric concentrations, respectively. This effect would be particularly significant, if a strong seasonal aerosol contrast prevail, as seen at coastal sites, among others for sulfur and nitrogen species (Minikin et al., 1998; Wagenbach et al., 1998a and 1998b). Second, some of the seasonal cycles observed in coastal aerosol records are not well understood yet and deserve to be contrasted to respective records from central Antarctic sites. This is especially true for the multi-mode nitrate cycle (Wagenbach et al., 1998b), ammonium (Legrand et al., 1998), the methane sulfonate (MS) to sulfate ratio (Legrand and Pasteur, 1998; Piel et al, 2006) and the cycle of sea salt versus sea ice derived sodium fraction (Rankin et al., 2002). For various reasons (snow and impurity redistribution, inadequate chronology) it would not be feasible to obtain such seasonal cycles at useful quality from high resolution snow pit studies at the inland sites.

Within the European Project for Ice Coring in Antarctica (EPICA), we attempted therefore to obtain year round data of the ionic aerosol composition by deploying an automated aerosol sampler at the EPICA drill site in Dronning Maud Land (EDML). Here, we present an overview on the first results gained from the sampling campaigns at the unmanned Kohnen drill camp between February 2003 and December 2005, which complete our extensive summer samplings performed during the drilling seasons 2000 to 2002 (Piel et al., 2006). Herewith, emphasis is on assessing the performance of the technical approach, the reliability of the year round records as well as on the feasibility to deploy them for deep ice core related firn/air investigations. 


\section{Techniques}

\subsection{Site description and sampling technique}

Kohnen Station $\left(75^{\circ} \mathrm{S}, 0^{\circ} \mathrm{E}\right.$,), serving as summer camp during the EDML deep drilling activities, is located $2892 \mathrm{~m}$ a.s.l. with the nearest distance to the Atlantic sector coast of roughly $520 \mathrm{~km}$ (see Fig. 1). The glacio-meteorological site conditions are characterized by a relatively low net snow accumulation rate around $71 \pm 21 \mathrm{~kg} \mathrm{~m}^{-2} \mathrm{yr}^{-1}$ (Oerter et al., 1999), an annual mean temperature of $-46^{\circ} \mathrm{C}$ ( typically ranging between $-15^{\circ} \mathrm{C}$ and $-70^{\circ} \mathrm{C}$ ) and a moderate annual mean wind speed wind of about $4.6 \mathrm{~m} / \mathrm{s}$ (mainly persisting from northeast) (Reijmer, 2001). The prominent origin of air masses reaching Kohnen Station is the South Atlantic as shown by a thorough back trajectory analysis (Reijmer et al., 2002)

The automatic year round sampling of aerosol filters for subsequent ion analyses started at Kohnen in February 2003 based on a dedicated satellite-station and is still ongoing. Since the detailed outline of this sampling station will be given elsewhere, only the essential technical feature is briefly presented here. We installed the automated aerosol sampler inside a specially insulated 20' container. The operating aerosol sampler has a continuous power consumption between 6-7 W at 12 VDC. Electric power was supplied by solar panels and a wind turbine, backed up with 1070 Ah nickel-cadmium batteries which have proven to be operative down to $-50^{\circ} \mathrm{C}$. This ensured a continuous sampling and minimized outages due to wind velocities below around $3 \mathrm{~m} / \mathrm{s}$ during polar night, when the power supply relies entirely on the wind turbine.

The automatic sampling basically follows the concept developed by Preunkert and Wagenbach (1998) and Preunkert et al. (2002), which rely on consecutive activation of individual filter holder/pump units. Apart from various measures to cope with temperatures down to $70^{\circ} \mathrm{C}$, substantial updates of the previous version (to be deployed at high alpine sites) mainly concerned the improvement of the automatic filter sealing during the pre- and post sampling 
period and an all PFA (polyfluoralkoxy-copolymer) inline design. The sampling time was fixed to 15 days (corresponding to a typical air volume of $60 \mathrm{~m}^{3} \mathrm{STP}$ ), which for the given power supply reflects a reasonable compromise between temporal resolution and analytical sensitivities (i.e. quantitative detection limits). In principle, ambient air was sucked in through a single inlet and was directed to 22 sampling units each consisting of a PFA inline filter holder, a one-way inlet and outlet valve and a miniature vacuum pump (carbon vane pump) as outlined in Figure 2. The sampling line was about $2 \mathrm{~m}$ long (PFA, inner diameter $8 \mathrm{~mm}$ ) and its orifice was fixed $1 \mathrm{~m}$ above the container top resulting in a total sampling height of around $5 \mathrm{~m}$. To minimize the danger of passive sampling, we avoided permanent contact of the filters with ambient air by isolating each inline filter holder via squeezing valves at the entrance and outlet (Figure 2). Appropriate working of the valves was ensured using silicon tubing for the pinching unit which remains flexible even at temperatures down to $-50^{\circ} \mathrm{C}$. A programmable data logger managed the control of the procedure cycle. Two-stage filter systems were deployed at a ambient air flow rate of 3-4 1/min, which included an upstream teflon (Millipore, $47 \mathrm{~mm}$ diameter, $1 \mu \mathrm{m}$ pore size) and a downstream nylon filter (Gelman Nylasorb, $47 \mathrm{~mm}$ diameter, $1 \mu \mathrm{m}$ pore size). The teflon filter collected all particulate compounds with efficiencies higher than $95 \%$ but allows gaseous (acidic) species like $\mathrm{HCl}, \mathrm{HNO}_{3}$ to pass through as becoming partly adsorbed on the nylon filter (Piel et al., 2006). It is expected that these volatile species, which may be possibly desorbed from the front filter during the rather long post sampling storage were sampled by the nylon back up filter as well. Consequently, we did not attempt to differentiate between the particulate fractions of nitrate and chloride, respectively, but report the total concentrations of these species.

For a comparison we referred to the 22 years (1983-2005) record of continuous and ongoing aerosol sampling at Neumayer (e.g. Legrand and Pasteur, 1998; Wagenbach et al., 1998a and 1998b). The mean seasonality of ion concentrations measured at this coastal site is of clima- 
tologic relevance due to the long observation period. A description of the sampling procedure at Neumayer is given in Wagenbach et al. (1988). In short, these data were based on a sampling period of typically 7 days, occasionally extented up to two weeks. In contrast to Kohnen, two Whatman ${ }^{\mathrm{TM}} 541$ cellulose filters were used in series instead of a teflon/nylon combination.

\subsection{Filter analyses}

The filters were rigorously pre-cleaned at the Institute für Umweltphysik (IUP) by shaking them several days in steadily renewed de-ionized water (i.e. $18.2 \mathrm{M} \Omega \mathrm{cm}^{-1}$ ) until no significant enhancement of the electrolytic conductivity of the washing water could be observed. They were dried in a stream of particle free air, cleaned as well from contaminating trace gases by acidic, alkaline and activated carbon cartridges, respectively. The dry filter were subsequently loaded in a clean air laboratory face to face into PFA inline filter holders, which were capped by airtight stopcocks and finally sealed in aluminium lined polythene bags. After collection, the filters holders with the aerosol samples were again capped, sealed in polythene-aluminium bags and transported at $-25^{\circ} \mathrm{C}$ to our home laboratory in Bremerhaven. While we applied a common extraction of the nylon and teflon filters for the 2003 and 2004 sampling campaigns, the 2005 samples were extracted separately. The analytical procedure included wetting of the teflon filter by $100 \mu 1$ 2-propanol, soaking and shaking in $20 \mathrm{ml}$ milliQ water, followed by ultrasonic treatment for 15 minutes and subsequent ion chromatography (IC) analyses. In general, samples were analyzed for methane sulfonate (MS), $\mathrm{Cl}^{-}, \mathrm{Br}^{-}$, $\mathrm{NO}_{3}{ }^{-}, \mathrm{SO}_{4}{ }^{2-}$, oxalate $\left(\mathrm{C}_{2} \mathrm{O}_{4}{ }^{2-}\right), \mathrm{Na}^{+}, \mathrm{NH}_{4}{ }^{+}, \mathrm{K}^{+}, \mathrm{Mg}^{2+}$, and $\mathrm{Ca}^{2+}$. According to this analytical procedure the IC blank levels were between $0.2 \mathrm{ng} \mathrm{g}^{-1}$ and $0.3 \mathrm{ng} \mathrm{g}^{-1}$, except for $\mathrm{Br}^{-}$(around $1 \mathrm{ng} \mathrm{g}^{-1}$ ), $\mathrm{NH}_{4}{ }^{+}$, and $\mathrm{Ca}^{2+}$ (around $0.5 \mathrm{ng} \mathrm{g}^{-1}$ ). Details of the IC set up, accuracy and detection limit of the IC procedure correspond to those reported by Göktas (2002) and Piel (2004). 


\subsection{Uncertainties and data evaluation}

As expected, the variability of the filter blanks clearly governed the overall accuracy and thus the analytical detection limits as well. These estimates were derived from the variation of 17 identically processed procedure blanks which include possible contributions by the previously cleaned filters, and any effects arising from handling and long term storage (Table 1). The latter, systematic effect appeared to dominate the overall blank and we conservatively estimated the detection limits (DL) as three times the standard deviation (std) of these overall blank values, listed in Table 1. In addition to this blank induced uncertainty, relative errors of the flow meter $(< \pm 10 \%)$ and the IC calibration error $\left( \pm 10 \%\right.$ for oxalate, $\mathrm{NH}_{4}^{+}, \mathrm{Mg}^{2+}$ and $\mathrm{Ca}^{2+}$ and $\pm 5 \%$ for all other ions) were considered. In short, the combined uncertainty was found to be approximately $\pm 15 \%$ to $\pm 20 \%$ for ion concentrations above three times the corresponding detection limit (DL). It increased from around $\pm 20 \%$ to $\pm 40 \%$ approaching $3 \times$ DL level to $(-100 /+50) \%$ close to the detection limit. The concentrations for the cations $\mathrm{K}^{+}, \mathrm{Mg}^{2+}$, and $\mathrm{Ca}^{2+}$ were too low to calculate reliable $\mathrm{nss}-\mathrm{K}^{+}, \mathrm{nss}-\mathrm{Mg}^{2+}$, and $\mathrm{nss}-\mathrm{Ca}^{2+}$ values and bromide was below the IC detection limit of $\sim 1 \mathrm{ng} \mathrm{g}^{-1}$ throughout, corresponding to $0.34 \mathrm{ng} \mathrm{m}^{-3}$. In case of oxalate and $\mathrm{NH}_{4}{ }^{+}$overall blanks and most of the atmospheric concentrations appeared suspiciously high compared to atmospheric concentrations typical for coastal Antarctica (Legrand et al., 1998), hence we tentatively attribute these results to a specific contamination problem. In addition overall blanks and their variability were unusually high for MS and $\mathrm{Ca}^{2+}$. Here, a potential contamination during filter handling should be less critical compared to the ubiquitous ions $\mathrm{Cl}^{-}, \mathrm{NO}_{3}{ }^{-}, \mathrm{SO}_{4}{ }^{2-}$, and $\mathrm{NH}_{4}{ }^{+}$. Especially $\mathrm{Ca}^{2+}$ blank values were suspect, which exceeded the $\mathrm{Mg}^{2+}$ and even $\mathrm{Na}^{+}$ones. Concerning MS, part of the procedure blank (about 20-30\%) could be traced back to 2-propanol used for filter extraction causing a fake peak at the same elution time as MS. The remaining part may be due to passive sampling of gaseous 
MSA at the measuring site. For $\mathrm{Ca}^{2+}$ on the other hand, passive sampling should be negligble and we tentatively attribute the blanc problem to an unknown contamination during sample handling. While for MS only values observed from May through September were at or below the DL of $2.7 \mathrm{ng} \mathrm{m}^{-3}$ and thus seriously influenced by contamination, for $\mathrm{Ca}^{2+}$ this was unfortunately the case for nearly all samples. According to the overall uncertainties of the different

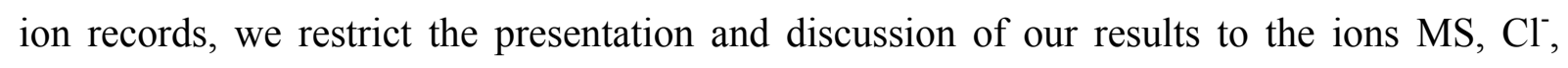

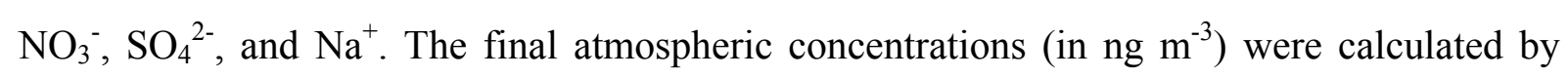
summing up the blank corrected ion amounts of the teflon and nylon filter of each sample and corrected the sampled air volume to standard conditions $(273.16 \mathrm{~K}$ and $1013 \mathrm{hPa})$.

Non-sea salt sulfate (nss-SO ${ }_{4}^{2-}$ ) concentrations were calculated by subtracting the concentration of the sea salt derived sulfate from the total $\mathrm{SO}_{4}{ }^{2-}$ concentration (in $\mathrm{ng} \mathrm{\textrm {g } ^ { - 1 }}$ ). We used $\mathrm{Na}^{+}$as sea salt reference species and the sulfate to sodium ratio in bulk sea water of $\alpha_{\text {sulfate }}=$ 0.252 for November to February, and due to the potential impact of sea salt fractionation by frost flower formation $\alpha_{\text {sulfate }}=0.07$ for winter (March - October) samples, i.e.:

$$
\left(\text { nss- } \mathrm{SO}_{4}{ }^{2-}\right)=\left(\mathrm{SO}_{4}{ }^{2-}\right)-\alpha_{\text {sulfate }} \times\left(\mathrm{Na}^{+}\right)
$$

Note that due to low sea salt aerosol concentrations the impact of sea salt fractionation on the nss- $\mathrm{SO}_{4}{ }^{2-}$ budget at Kohnen was in most cases negligible, except during the sporadic occurrence of peaking sea salt aerosol loadings happened mainly during winter. A determination of sea salt $\mathrm{Na}^{+}$by correcting the mineral dust portion of the $\mathrm{Na}^{+}$signal according to Bigler et al. (2006) was not possible due to $\mathrm{Ca}^{2+}$ levels typically below the detection limit. However, even in the worst case, a mineral dust correction would change the $\mathrm{Na}^{+}$concentrations by less than about 5\%. 


\section{Data Presentation}

Figs. 3 to 5 give an overview of our EDML aerosol measurements for the ions MS, nss$\mathrm{SO}_{4}{ }^{2-}, \mathrm{Na}^{+}$, and $\mathrm{NO}_{3}{ }^{-}$. Note that for each component two samples taken in 2004 between Sep. 21 and Oct. 5 as well as between Nov. 7 and Nov. 21 were removed because of inadequately low sampling volumes of $17 \mathrm{~m}^{3}$ and $14 \mathrm{~m}^{3}$, respectively. A total loss of the wind turbine controller caused a break-down of aerosol sampling between mid of April to the end of October in 2003, while during 2004 we obtained reliable data from the periods February to the end of June and from mid of September to December. The reason for a data gap over 11 weeks in winter 2004 was again malfunction of the wind turbine leading to empty backup batteries, while during 2005 just one sample was lost in September. Due to maintenance of the system, no automatic samplings were performed in January. Each value shown in Figs. 3 to 5 represents a sampling period over 360 hours (15 days). Concerning the accuracy of the data, we omitted error bars for clarity and refer to the outline in chapter 2.3. Table 1 summarizes mean and standard deviation for all ionic compounds measured at Kohnen. Due to missing data for the month January and the mentioned sampling gaps during winter, a bias in calculating annual mean and median concentrations from the whole data set would result. Hence, we included adequately weighted the results from three summer campaigns performed between January and early February in the years 2000, 2001, and 2002 (Piel et al., 2006) and padded missing winter data with the medium winter concentrations for the year 2005.

In Figs. 6 to 9, addressing the seasonality of the ionic aerosol compounds, we merged the results obtained by automatic sampling with those from the mentioned three summer campaigns. It is important to note that the values from these summer campaigns were consistent with those obtained during that season by the automated aerosol sampler. Also illustrated in Figs. 6 to 9 are the main seasonal cycles at the coastal Neumayer Station as to be compared with the Kohnen ones. 


\section{Discussion}

\section{1. $\mathrm{MS}$ and $\mathrm{nss}-\mathrm{SO}_{4}{ }^{2-}$}

Based on aerosol measurements conducted during three summer campaigns, Piel et al. (2006) reported on the origin of atmospheric sulfur at Kohnen in detail addressing the fraction of non-biogenic sulfur and the variability of $\mathrm{MS} / \mathrm{nss}^{-\mathrm{SO}_{4}}{ }^{2-}$ ratios $\beta_{\mathrm{MS}}$. In completing this study, we focus here on seasonal aspects of the sulfur budget at Kohnen.

Comparison of the year-round MS and nss- $\mathrm{SO}_{4}{ }^{2-}$ concentrations at Kohnen with Neumayer revealed broadly the same seasonality for both species with corresponding maximum concentrations during austral summer. If we include our MS and nss- $\mathrm{SO}_{4}{ }^{2-}$ results of $51 \pm 28 \mathrm{ng} \mathrm{m}^{-3}$ (mean \pm std) and $280 \pm 100 \mathrm{ng} \mathrm{m}^{-3}$, respectively, obtained during three composite summer campaigns at Kohnen, the resulting annual mean concentrations were found to be a factor of 2.6 and 1.6 lower, compared to the long-term means at coastal Neumayer (see Table 1). A more detailed comparison of the seasonality between these two sites is shown in Fig. 10. At Kohnen the summer MS maximum appeared less sharp and even the fall (i.e. March and April) MS concentrations were relatively high. Interestingly, only during summer MS concentrations were clearly lower at Kohnen, while during all other seasons they were roughly comparable to Neumayer. Thus the higher annual mean values at Neumayer were essentially caused by the summer maxima. The seasonal cycle of MS at Neumayer appears to be a composite of a flat maximum lasting from December to March superimposed by a sharp peak in January, which was obviously absent at Kohnen. As discussed by Minikin et al. (1998), particularly marine sources south of $60^{\circ} \mathrm{S}$ seem to dominate the MS level at Neumayer, while for nss- $\mathrm{SO}_{4}{ }^{2-}$ also long range transport of biogenic sulfur from more northern regions of the South Atlantic were relevant. We infer that the biogenic sulfur seen at Kohnen was more representa- 
tive for the Southern Ocean as a whole, while at Neumayer also a regional impact from the Antarctic part of the South Atlantic was discernible, particularly for MS.

Comparable to Neumayer we found a significant correlation between MS and nss- $\mathrm{SO}_{4}{ }^{2-}$ concentrations at Kohnen (Fig. 11). However, the inter-site difference in the seasonal biogenic sulfur maximum was also reflected in the individual $\mathrm{MS} / \mathrm{nss}^{-} \mathrm{SO}_{4}{ }^{2-}$ ratios $\left(\beta_{\mathrm{MS}}\right)$ which reached at Kohnen its maximum of 0.33 during fall while at Neumayer a maximum value of 0.36 appeared during summer. Especially during winter, but also in spring and fall, at both sites the uncertainty of $\beta_{\mathrm{MS}}$ ratios were as large as the calculated values itself due to low MS and sulfate concentrations and difficulties to derive reliable nss- $\mathrm{SO}_{4}{ }^{2-}$ concentrations. The latter problem was mainly caused by the potentially varying and unknown impact of sea salt fractionation (Wagenbach et al. (1998a); Rankin et al. (2002)) entailing an uncertain value of $\alpha_{\text {sulfate }}$ needed in equation (1). Using $\alpha_{\text {sulfate }}=0.07$, wintertime nss- $\mathrm{SO}_{4}{ }^{2-}$ persisted at 5 to 35

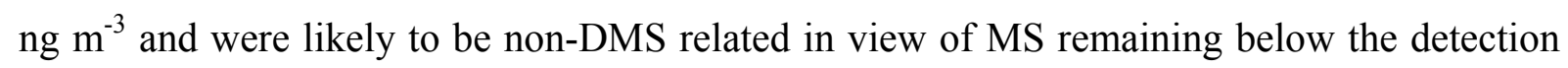
limit of $2.7 \mathrm{ng} \mathrm{m}^{-3}$. Concerning the atmospheric sulfur inventory during winter at other inland sites, only atmospheric sulfur measurements were available, conducted at South Pole during the years 1979 to 1983 by Tuncel et al. (1989), whereas nss-SO ${ }_{4}^{2-}$ South Pole data from July 1992 to December 1992 were reported by Harder et al. (2000). Winter concentrations of 5-50 ng m $\mathrm{m}^{-3}$ (Harder et al., 2000) and 21 $\pm 13 \mathrm{ng} \mathrm{m}^{-3}$ (Tuncel et al., 1989) at South Pole were consistent with the level observed at Kohnen.

\subsection{Sea Salt}

The common mechanism producing sea salt aerosol is bubble bursting during whitecap formation caused by surface winds over open ocean waters (Monahan et al., 1986). For polar regions, the formation of sea salt aerosols by frost flowers on freshly formed sea ice has been put forward as alternative source (Rankin et al., 2000 and 2002; Wolff et al., 2003). This 
assumption challenges a revision of the hitherto adopted interpretation that sea salt signals in ice cores should be a proxy for storminess and meridional transport (Petit et al., 1999).

In the following, we used $\mathrm{Na}^{+}$as a gauge for sea salt aerosol amount. Basically, $\mathrm{Na}^{+}$concentrations measured at Neumayer were an order of magnitude higher compared to Kohnen, which is clearly due to the source proximity at Neumayer. A broad seasonal maximum of $\mathrm{Na}^{+}$ concentrations was evident at both stations during winter, but somewhat more pronounced at Kohnen (Fig. 8). Our findings were consistent with investigations by Hara et al., (2004) performed at the coastal Japanese Station Syowa and its continental counterpart Dome Fuji. These authors found at Dome Fuji maximum $\mathrm{Na}^{+}$concentrations of around $60 \mathrm{ng} \mathrm{m}^{-3}$ from May-November. $\mathrm{Na}^{+}$concentrations at Syowa were on average an order of magnitude higher. At South Pole, they decreased from roughly around 20-80 $\mathrm{ng} \mathrm{m}^{-3}$ between July and October to typically less than $10 \mathrm{ng} \mathrm{m}^{-3}$ in November and December (Bodhaine et al., 1986 and Harder et al., 2000). Except for Dumont d'Urville, a seasonal sea salt aerosol maximum during winter was generally observed in Antarctica (Hara et al., (2004) and references therein).

In order to assess the impact of potentially sea ice derived sea salt aerosol seen at Kohnen we compiled a ternary diagram of the $\mathrm{SO}_{4}{ }^{2-}, \mathrm{Na}^{+}$, and $\mathrm{Cl}^{-}$composition of the aerosol (Fig. 12). For presentation we followed the approach of Rankin et al. (2002) and normalized the data such that the composition corresponding to pure seawater sea salt is localized in the centre of the diagram:

$$
\begin{aligned}
& \mathrm{Na}^{+} \text {-ratio }=\left(\left[\mathrm{Na}^{+}\right] / 10.76\right) /\left(\left[\mathrm{Na}^{+}\right] / 10.76+\left[\mathrm{Cl}^{-}\right] / 19.35+\left[\mathrm{SO}_{4}{ }^{2-}\right] / 2.712\right) \\
& \mathrm{Cl}^{-} \text {-ratio }=\left(\left[\mathrm{Cl}^{-}\right] / 19.35\right) /\left(\left[\mathrm{Na}^{+}\right] / 10.76+\left[\mathrm{Cl}^{-}\right] / 19.35+\left[\mathrm{SO}_{4}{ }^{2-}\right] / 2.712\right) \\
& \mathrm{SO}_{4}{ }^{2-} \text {-ratio }=\left(\left[\mathrm{SO}_{4}{ }^{2-}\right] / 2.712\right) /\left(\left[\mathrm{Na}^{+}\right] / 10.76+\left[\mathrm{Cl}^{-}\right] / 19.35+\left[\mathrm{SO}_{4}{ }^{2-}\right] / 2.712\right)
\end{aligned}
$$

where [ion] is the ion concentration in the aerosol sample in $\mathrm{ng} \mathrm{m}^{-3}$. The diamond in Fig. 12 marks the composition of totally fractionated sea salt (i.e. all sulfate precipitated as mirabilite, $\mathrm{Na}_{2} \mathrm{SO}_{4} \bullet 10 \mathrm{H}_{2} \mathrm{O}$ ). Within the hatched area sulfate depleted, i.e. frost flower sea salt aerosol 
(with varying $\mathrm{Cl}^{-}$portions) would be located. According to this ternary diagram, it seems that no fractionated sea salt had reached Kohnen Station during the observation period. However, this conclusion is surely ambiguous because even during winter a possible sea salt sulfate (ss$\mathrm{SO}_{4}{ }^{2-}$ ) depletion could easily be compensated by nss- $\mathrm{SO}_{4}{ }^{2-}$, especially given the low sea salt aerosol level at Kohnen (Fig. 8; mean \pm std: $23.8 \pm 25 \mathrm{ng} \mathrm{m}^{-3} \mathrm{Na}^{+}$). Generally, the composition of fractionated sea salt aerosol with a surplus of nss- $\mathrm{SO}_{4}{ }^{2-}$ was consistent with the dotted line in Fig. 12, while the dashed line represents the composition of seawater sea salt plus a surplus of nss- $\mathrm{SO}_{4}{ }^{2}$. In view of the rather high uncertainty of our measured points both lines are too close together to differentiate between both processes. Therefore, the current $\mathrm{Na}^{+}$and $\mathrm{SO}_{4}{ }^{2-}$ data from Kohnen did not allow to decide to what extent the winter time sea salt aerosol at central Antarctica has been fractionated and hence would originate from a potential sea-ice source. At South Pole and Dome F, sea salt concentrations during winter were well below $100 \mathrm{ng} \mathrm{m}^{-3}$ (see above), implicating that also at other continental sites an assessment of sea salt fractionation via sulfate depletion should remain ambiguous at least for weekly and longer sampling periods. At Neumayer, on the other hand, a significant $\mathrm{Na}^{+}$and sulfate depletion indicated the substantial role of sea ice as an additional sea salt source (Minikin et al., 1998; Wagenbach et al., 1998a).

\subsection{Nitrate}

To our knowledge, no atmospheric nitrate measurements are made up so far in continental Antarctica, except during austral summer. Representative year-round observations of total $\mathrm{NO}_{3}{ }^{-}$(Wagenbach et al., 1998b) and measurements of gaseous reactive nitrogen oxides $\left(\mathrm{NO}_{\mathrm{y}}\right)$ (Weller et al., 2002) are available, however, at various coastal Antarctic sites. They indicated that the input of stratospheric nitrate may constitute the dominant sources there, including to 
some extent seasonal intrusions of stratospheric $\mathrm{NO}_{\mathrm{y}}$ and sedimentation of polar stratospheric clouds (PSC).

Specifically at inland sites, part of the boundary layer nitrate is re-emitted from firn as $\mathrm{HNO}_{3}$, which may impose a certain imprint on the atmospheric nitrate seasonality. For Kohnen, Weller et al. (2004) reported significant post depositional losses of nitrate (and MSA), most probably restricted to the summer months. Therefore, as shown by Piel et al. (2006) for MS, the measured total nitrate during austral summer at Kohnen may be partly attributed to re-emitted $\mathrm{HNO}_{3}$ from upper firn layers. Indeed, denuder measurements during summer revealed that between $33 \%$ and $76 \%$ of the total nitrate was present there as free acid $\mathrm{HNO}_{3}$ (Piel et al. 2006). Following this approach with a corresponding nitrate loss of about $26 \%$, i.e. $20 \pm 12 \mathrm{ng} \mathrm{g}^{-1}$ (Weller et al., 2004) and considering an annual snow accumulation of $71 \mathrm{~kg} \mathrm{~m}^{-2}$, yielded a $\mathrm{HNO}_{3}$ emission flux $\Phi_{\mathrm{em}}\left(\mathrm{HNO}_{3}\right)$ of $(45 \pm 27) \times 10^{-3} \mathrm{ng} \mathrm{m}^{-2} \mathrm{~s}^{-1}$. This would be sufficient to replenish a $100 \mathrm{~m}$ thick local atmospheric inversion layer within one day to maintain a nitrate concentration of around $40 \mathrm{ng} / \mathrm{m}^{3}$ (neglecting any $\mathrm{HNO}_{3}$ sinks). Thus reemitted nitrate might have significantly influenced our Kohnen nitrate observations, at least during the summer half years.

Following Fig. 9, the seasonality of total nitrate at Kohnen agreed surprisingly well with long-term observations from Neumayer Station (Wagenbach et al., 1998b), though the absolute values were somewhat higher at Neumayer. In view of this systematic difference, we cannot rule out that $\mathrm{HNO}_{3}$ may have been partly lost in the up-stream area of the automatic sampler or during filter storage, though the January means obtained by Piel et al. (2006) did not significantly differ from the automatic sampling in December and February. Note however, that the Kohnen data reflect total nitrate, similar to Neumayer, where two Whatman ${ }^{\mathrm{TM}}$ 541 cellulose filters were used in series and where the relatively high sea salt load ensured total nitrate sampling even during high acid loads in summer (as discussed in Wagenbach et 
al. (1998b)). Apart from the prominent nitrate maximum in November, secondary peaks during August to September and around February are regularly seen at Neumayer, which were attributed by Wagenbach et al. (1998b) to PSC and stratospheric air mass intrusions, respectively. While the nitrate minimum as well as the maximum in November and a secondary peak during January-February were also evident at Kohnen, there was no clear indication for a late winter peak. However, regarding our limited number of data points especially during this period the latter finding appears not conclusive, yet. The rather good correspondence of the seasonal nitrate cycles between Neumayer and Kohnen appears to be somewhat conflicting as suggesting the following implications:

(1) The latitudinal position of the sampling site relative to the Antarctic vortex (also associated with the height above sea level) may not play an important role. Given that in contrast to Neumayer, Kohnen is almost permanently below the Antarctic vortex, the seasonality of PSC sedimentation and stratospheric air mass intrusions should be of secondary importance in shaping the seasonal cycle of boundary layer nitrate.

(2) Because post depositional losses of $\mathrm{NO}_{3}{ }^{-}$are only significant at sites with annual snow accumulations below $100 \mathrm{~kg} \mathrm{~m}^{-2}$ (Röthlisberger et al., 2002; Weller et al., 2004), they are only relevant for inland sites. Thus, $\mathrm{NO}_{3}{ }^{-}$re-emissions do either not substantially contribute to the nitrate budget of the inland boundary layer, or instead, they are strong enough to impose an Antarctic wide impact seen at coastal sites as well. In this context it is worthwhile to mention, that although the extremely depleted $\delta^{15} \mathrm{~N}$ in atmospheric nitrate at Neumayer would be consistent with a significant nitrate source by re-emission (Wagenbach et al., 1998b), an almost negligible contribution on the nitrate budget of the entire Antarctic troposphere has been estimated by these authors. 


\section{Conclusion}

We demonstrated that year-round aerosol chemistry records can be obtained from the Antarctic Plateau by deploying an unattended automated aerosol sampler, even though there was a higher probability of missing data during winter. Energy restrictions during polar night basically limited the sampling flow rate and thus the time resolution to bi-weekly samplings. Based on these constraints, including passive and post-sampling artefacts, reliable ion records of biogenic sulfur species, sea salt and total nitrate could be obtained, while the filter blank variability needs still to be improved to gain meaningful mineral dust related ion records.

On the one hand, the main feature of the seasonal cycles at the Kohnen inland position are found to be broadly in agreement with respective long-term observations from the coastal Neumayer Station. Except in the case of total nitrate, this general finding might have been expected, though the atmospheric concentration levels at the inland site were unknown. On the other hand, evidences for small, nevertheless important inter-site differences could be revealed, emphasising the need for long term aerosol chemistry records from central Antarctic positions to interpret related ice core records. Among others, the differences of the Kohnen records relative to coastal ones mainly comprise: (1) a higher summer/winter contrast in the sea salt level, and (2) a less confined summer maxima of biogenic sulfur species, which extended more far into late summer/fall. Both observations might be related to the obviously less proximate situation of Kohnen Station to the principal sources of these marine aerosol components, underlying the importance of atmospheric transport not only for the absolute atmospheric levels, but also for the seasonal changes.

Based on the bi-weekly sampling interval it was not possible to clearly identify the arrival of depleted ss- $\mathrm{SO}_{4}{ }^{2-}$, which would help to indicate the relative importance of the sea ice related source at this position. It is evident, that this finding is due to a nss- $\mathrm{SO}_{4}{ }^{2-}$ to $\mathrm{Na}^{+}$ratio generally too high for clearly detecting the depletion. Although a much higher sampling 
resolution may help to capture events with a lower and hence more favourable nss- $\mathrm{SO}_{4}{ }^{2-}$ to $\mathrm{Na}^{+}$ratio, this attempt would be hardly feasible by an automatic sampler.

Obviously, ionic signals archived in firn do not straightforwardly depend on the atmospheric loading of the boundary layer at the drilling site but are, among others, also governed by various deposition processes. In conclusion, deploying year round aerosol records as exemplarily presented here, a dedicated improvement of related ice core interpretations needs to consider concurrent observations from snow accumulation records by e.g. automated weather stations, which should be backed up by sub-seasonal resolution snow pit data. For this attempt, the seasonalities of the atmospheric loads as well as of the precipitation strongly matters, since their interference eventually determines the mean firn levels as well as its relation to the deposition processes involved.

\section{Acknowledgements}

This work is a contribution to the European Project for Ice Coring in Antarctica (EPICA), a joint European Science Foundation/European Commission scientific programme, funded by the EU and by national contributions from Belgium, Denmark, France, Germany, Italy, the Netherlands, Norway, Sweden, Switzerland and the United Kingdom. The main logistic support was provided by IPEV and PNRA (at Dome C) and AWI (at Dronning Maud Land). This is EPICA publication no. 169. IUP acknowledges substantial financial support through a specific AWI grant. Invaluable help came from the technicians and scientists of the Kohnen summer campaign and the IUP work shop staff. Thereby we wish to thank Johannes Käßbohrer, Urs Ruth, Dorothee Dick, Cord Drücker, Rainer Fletterer, and Ralph Pfeiffer for their particular efforts. Finally we wish to thank the two anonymous reviewers for their very helpful comments. 


\section{References}

Arimoto, R., Nottingham, A.S., Webb, J., Schloesslin, C.A., Davis, D.D. 2001. Non-sea Salt Sulfate and Other Aerosol Constituents at the South Pole during ISCAT. Geophys. Res. Lett. 28(19), 3645-3648.

Arimoto, R., Hogan, A., Grube, P., Davis, D., Webb, J., Schloesslin, C., Sage, S., Raccah, F. 2004. Major ions and radionuclides in aerosol particles from the South Pole during ISCAT2000. Atmos. Environ. 38, 5473-5484.

Bigler, M., Röthlisberger, R., Lambert, F., Stocker, T. and Wagenbach D. 2006. Aerosol deposited in East Antarctica over the last glacial cycle: Detailed apportionment of continental and sea-salt contributions. J. Geophys. Res. 109(D08205), doi:10.10129/2005JD006469.

Bodhaine, B.A., Deluisi, J.J., Harris, J.M., Houmere, P. and Bauman S. 1986. Aerosol measurements at the South Pole. Tellus 38B, 223-235.

de Mora, S.J., Wylie, D.J. and Dick, A.L. 1997. Methanesulphonate and non-sea salt sulfate in aerosol, snow and ice on the east Antarctic plateau. Antarctic Science 9(1), 46-55.

EPICA Community Members. 2006. One-to-one coupling of glacial climate variability in Greenland and Antarctica. Nature 444, 195-198, doi:10.1038/nature05301.

Göktas, F. 2002. Characterization of glacio-chemical and glacio-meteorological parameters on Amundsenisen, Dronning Maud Land, Antarctica. In: Reports on Polar and Marine Research, 425 (ed. F. Riemann). Alfred-Wegener-Inst. for Polar and Marine Res., Bremerhaven, 29-41.

Hara, K., Osada, K., Kido, M., Hayashi, M., Matsunaga, K., Iwasaka, Y., Yamanouchi, T., Hashida, G. and Fukatsu T. 2004. Chemistry of sea-salt particles and inorganic halogen species in Antarctic regions: Compositional differences between coastal and inland stations. J. Geophys. Res. 109(D20208), doi:10.10129/2004JD004713. 
Harder, S., Warren, S.G. and Charlson, R.J. 2000. Sulfate in air and snow at the South Pole: Implications for transport and deposition at sites with low snow accumulation. J. Geophys. Res. 105(D18), 22 825-22 832.

Hastings, M.G., Sigman, D.M., Steig E.J. 2005. Glacial/interglacial changes in the isotopes of nitrate from the Greenland Ice Sheet Project 2 (GISP2) ice core. Global Biogeochem. Cycles 19, GB4024, doi:10.1029/2005GB002502.

Jonsell, U., Hansson, M.E., Mörth, C.-M. and Torssander P. 2005. Sulfur isotopic signals in two shallow ice cores from Dronning Maud Land, Antarctica. Tellus 57B, 341-350.

Jourdain, B. and Legrand M. 2001. Year-round records of bulk and size-segregated aerosol composition and $\mathrm{HCl}$ and $\mathrm{HNO}_{3}$ levels in the Dumont d'Urville (coastal Antarctica) atmosphere: Implications for sea-salt aerosol fractionation in the winter and summer. $J$. Geophys. Res. 107(D22), 4645, doi:10.1029/2002JD002471.

König-Langlo, G., King, J.C., Pettré, P. 1998. Climatology of the three coastal Antarctic stations Dumont d'Urville, Neumayer and Halley. J. Geophys. Res. 103(D9), 10 935-10 946.

Legrand, M. and Mayewski, P. 1997. Glaciochemistry of polar ice cores: a review. Rev. Geophys. 35, 219-243.

Legrand, M. and Pasteur, E.C. 1998. Methane sulfonic acid to non-sea salt sulfate ratio in coastal Antarctic aerosol and surface snow. J. Geophys. Res. 103(D9), 10 991-11 006.

Legrand, M., Ducroz, F., Wagenbach, D., Mulvaney, R. and Hall, J. 1998. Ammonium in coastal Antarctic aerosol and snow: Role polar ocean and penguin emissions. J. Geophys. Res. 103(D9), 11 043-11 056.

Minikin, A., Legrand, M., Hall, J., Wagenbach, D., Kleefeld, C., Wolff, E., Pasteur, E.C. and Ducroz, F. 1998. Sulfur-containing species (sulfate and methanesulfonate) in coastal Antarctic aerosol and precipitation. J. Geophys. Res. 103(D9), 10 975-10990. 
Monahan, E.C., Spiel, D.E. and Davidson, K.L. 1986. A model of marine aerosol generation via whitecaps and wave disruption. In: Oceanic Whitecaps (ed. E. Monahan and G.M. Niocaill). D. Reidel, Norwell, Mass., 167-174.

Oerter, H., Graf, W., Wilhelms, F., Minikin, A. and Miller, M. 1999. Accumulation studies on Amundsenisen, Dronning Maud Land, Antarctica, by means of tritium, dielectric profiling and stable-isotope measurements: first results from the 1995-96 and 1996-97 field seasons. Ann. Glaciol. 29, 1-9.

Petit, J.R., Jouzel, J., Raynaud, D., Barkov, N.I., Barnola, J.-M., and co-authors. 1999. Climate and atmospheric history of the past 420,000 years from the Vostok ice core, Antarctica. Nature 399, 429-436.

Piel, C. 2004. Variabilität physikalischer und chemischer Parameter des Aerosols in der antarktischen Troposphäre. In: Reports on Polar and Marine Research 476 (ed. F. Riemann). Alfred-Wegener-Inst. for Polar and Marine Res., Bremerhaven, 91-110.

Piel, C., Weller, R., Huke, M. and Wagenbach, D. 2006. Atmospheric methane sulfonate and non-sea salt sulphate records at the EPICA deep-drilling site in Dronning Maud Land, Antarctica. J. Geophys. Res. 111(D03304), doi:10.1029/2005JD006213.

Preunkert, S. and Wagenbach, D. 1998. An automatic recorder for air/firn transfer studies of chemical aerosol species at remote glacier sites. Atmos. Environ. 32, 4021-4030.

Preunkert, S., Wagenbach, D. and Legrand, M. 2002. Improvement and characterization of an automatic aerosol sampler for remote (glacier) sites. Atmos. Environ. 36, 1221-1232.

Rankin, A.M., Auld, V. and Wolff, E.W. 2000. Frost flowers as a source of fractionated sea salt aerosol in the polar regions. Geophys. Res. Lett. 27(21), 3469-3472.

Rankin, A.M., Wolff, E.W. and Martin, S. 2002. Frost flowers: Implications for tropospheric chemistry and ice core interpretation. J. Geophys. Res. 107(D23), 4683, doi:10.10129/2002JD002492. 
Reijmer, C.H. 2001. Antarctic Meteorology - A study with Automatic Weather Stations, PhD-Thesis. University of Utrecht, 1-159.

Reijmer, C.H., van den Broeke, M.R., Scheele, M.P. 2002. Air parcel and snowfall related to five deep drilling locations in Antarctica based on ERA-15 Dataset. J. Climate 15, 19571968.

Röthlisberger, R., Hutterli, M.A., Wolff, E.W., Mulvaney, R., Fischer, H., and co-authors. 2002. Nitrate in Greenland and Antarctic ice cores: a detailed description of postdepositional processes. Annals of Glaciology, 35, 209-216.

Ruth, U., Wagenbach, D., Mulvaney, R., Oerter, H., Graf, W., Pulz, H., Littot, G. 2004. Comprehensive 1000 year climate history from an intermediate-depth ice core from the south dome of Berkner Island, Antarctica: methods, dating and first results. Ann. Glaciol. 39, 146-154.

Tuncel, G., Aras, N.K. and Zoller, W.H. 1989. Temporal variations and sources of elements in the South Pole Aatmosphere, 1. Nonenriched and moderately enriched elements. J. Geophys. Res. 94(D10), 13 025-13 038.

Udisti, R., Becagli, S., Benassai, S., Castellano, E., Fattori, I., Innocenti, M., Migliori, A., Traversi, R. 2004. Atmosphere - snow interaction by a comparison between aerosol and uppermost snow layers composition at Dome C (East Antartica). Ann. Glaciol. 39, 53-61.

Wagenbach, D. 1996. Coastal Antarctica: Atmospheric chemical composition and atmospheric transport. In: Chemical Exchange between the Atmosphere and polar snow (ed. E.W. Wolff and R.C. Bales). NATO ASI Series vol. 43, Springer-Verlag Berlin Heidelberg, 173-199.

Wagenbach, D., Görlach, U., Moser, K. and Münnich, K.O. 1988. Coastal Antarctic aerosol: the seasonal pattern of ist chemical composition and radionuclide content. Tellus 40B, 426436. 
Wagenbach, D., Ducroz, F., Mulvaney, R., Keck, L. Minikin, A., Legrand, M., Hall, J.S. and Wolff, E.W. 1998a. Sea salt aerosol in coastal Antarctic regions. J. Geophys. Res. 103(D9), $10961-10974$.

Wagenbach, D., Legrand, M., Fischer, H., Pichlmayer, F. and Wolff, E.W. 1998b. Atmospheric near-surface nitrate at coastal Antarctic sites. J. Geophys. Res. 103(D9), $11007-11020$.

Weller, R., Jones, A.E., Wille, A., Jacobi, H.-W., McIntyre, H.P., Sturges, W.T., Huke, M., Wagenbach, D. 2002. Seasonality of reactive nitrogen oxides $\left(\mathrm{NO}_{\mathrm{y}}\right)$ at Neumayer Station, Antarctica. J. Geophys. Res. 107(D23), 4673, doi:10.1029/2002JD002495.

Weller, R., Traufetter, F., Fischer, H., Oerter, H., Piel, C. and Miller, H. 2004. Post depositional losses of methane sulfonate, nitrate and chloride at the EPICA deep-drilling site in Dronning Maud Land, Antarctica. J. Geophys. Res. 109(D07301), doi:10.1029/2003/JD004189.

Wolff, E.W., Rankin, A.M., and Röthlisberger, R. 2003. An ice core indicator of Antarctic sea ice production. Geophys. Res. Lett. 30(22), 2158, doi:10.1029/2003GL018454.

Wolff, E.W., Fischer, H., Fundel, F., Ruth, U., Twarloh, B., and co-authors. 2006. Southern Ocean sea-ice extent, productivity and iron flux over the past eight glacial cycles. Nature 440, 491-496, doi:10.1038/nature04614. 
Table 1. Blank variability in $\mathrm{ng}$ per $47 \mathrm{~mm}$ diameter filter, detection limits (DL) as well as mean \pm std of the ionic concentrations observed via automatic aerosol sampling at Kohnen (2003-2005) including the results from three separate summer seasons. Mean \pm std concentrations observed at Neumayer Station for the 1983-2005 period are given for comparison. The blanks denote the corresponding procedure blanks for filter combinations installed for the whole wintering-over in the sampler $(n=17)$. Detection limits were calculated for a typical sampling volume of $57 \mathrm{~m}^{3} \mathrm{STD}$. Ammonium and oxalate results were most probably invalid due to contamination.

\begin{tabular}{|c|c|c|c|c|}
\hline Ion & $\begin{array}{l}\text { blank (ng) } \\
\text { mean } \pm \text { std }\end{array}$ & $\mathrm{DL}\left(\mathrm{ng} \mathrm{m}^{-3}\right)$ & $\begin{array}{c}\text { Kohnen } \\
\text { mean } \pm \text { std }\left(\text { ng m }^{-3}\right)\end{array}$ & $\begin{array}{c}\text { Neumayer } \\
\text { mean } \pm \text { std }\left(\mathrm{ng} \mathrm{m}^{-3}\right)\end{array}$ \\
\hline MS & $210 \pm 45$ & 2.7 & $17 \pm 25$ & $44 \pm 75$ \\
\hline $\mathrm{SO}_{4}^{2-}$ & $210 \pm 85$ & 4.5 & $90 \pm 91$ & $150 \pm 158$ \\
\hline $\mathrm{Cl}^{-}$ & $600 \pm 150$ & 8.9 & $38 \pm 47$ & $480 \pm 664$ \\
\hline $\mathrm{NO}_{3}^{-}$ & $170 \pm 55$ & 2.9 & $25 \pm 21$ & $42 \pm 32$ \\
\hline oxalate & $350 \pm 300$ & 16 & $(35 \pm 48)$ & not analysed \\
\hline $\mathrm{Na}^{+}$ & $18 \pm 5$ & 0.28 & $24 \pm 25$ & $270 \pm 330$ \\
\hline $\mathrm{NH}_{4}^{+}$ & $420 \pm 360$ & 19 & $(48 \pm 44)$ & $6.2 \pm 6$ \\
\hline $\mathrm{K}^{+}$ & $8.0 \pm 5$ & 0.26 & $2.7 \pm 2.2$ & $11 \pm 19$ \\
\hline $\mathrm{Mg}^{2+}$ & $24 \pm 12$ & 0.6 & $3.9 \pm 4.0$ & $41 \pm 45$ \\
\hline $\mathrm{Ca}^{2+}$ & $280 \pm 160$ & 8.4 & $1.3 \pm 5.7$ & $12.5 \pm 13$ \\
\hline
\end{tabular}




\section{Figure captions.}

Fig. 1. Geographical position of the EPICA drill site in Dronning Maud Land (Kohnen Station) in relation to the Neumayer over-wintering site.

Fig. 2: Diagram of the technical layout of the automated aerosol sampler installed at EDML. Abbreviations: P, carbon vane pumps (22); EF, exhaust filter; FH, filter holders (22); FM, flow meter; IV, inlet valves (22); OV outlet valves (22). To enhance clarity, only 3 out of 22 filter units are shown.

Fig. 3: Concentrations of MS (triangles) and nss- $\mathrm{SO}_{4}{ }^{2-}$ (circles) observed during the years 2003, 2004 and 2005 at Kohnen Station. Hatched areas mark sampler down times due to

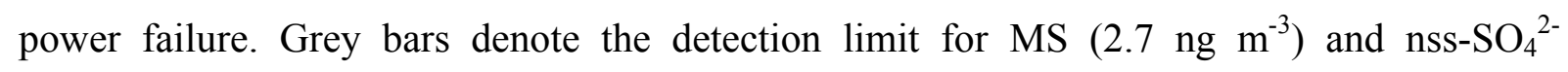
$\left(4.5 \mathrm{ng} \mathrm{m}^{-3}\right)$, respectively.

Fig. 4: Same as Fig. 2, but for $\mathrm{Na}^{+}$(triangles) and $\mathrm{Cl}^{-}$(circles). The grey bar marks the $8.9 \mathrm{ng} \mathrm{m}^{-3}$ detection limit of $\mathrm{Cl}^{-}$while that of $\mathrm{Na}^{+}\left(0.28 \mathrm{ng} \mathrm{m}^{-3}\right)$ is not displayed.

Fig. 5: Same as Fig. 2, but for $\mathrm{NO}_{3}{ }^{-}$with bold line denoting the $2.9 \mathrm{ng} \mathrm{m}^{-3}$ detection limit.

Fig. 6: Seasonal cycles of MS (open circles) at Kohnen (a) during the years 2003 to 2005, including mean results from 2000-2002 summer campaigns (filled circles) contrasted to the mean MS seasonality at Neumayer for the 1983-2005 period (b). Black bars represent monthly means from the corresponding site, dashed bold lines in (b) are again the monthly means from Kohnen for comparison. The bold grey line in (a) is the MS detection limit at Kohnen.

Fig. 7. Same as for Fig. 6, but for nss- $\mathrm{SO}_{4}{ }^{2-}$ concentrations (open circles: automated sampler, filled circles: separate summer campaigns) 
Fig. 8: Same as Fig. 6, but for $\mathrm{Na}^{+}$concentrations (open circles: automated sampler, filled circles: separate summer campaigns).

Fig. 9: Same as Fig. 6, but for $\mathrm{NO}_{3}{ }^{-}$concentrations (open circles: automated sampler, filled circles: separate summer campaigns).

Fig. 10: Mean seasonality of atmospheric MS at Kohnen (a) and Neumayer (b). For Kohnen, the results from three additional summer campaigns were displayed by grey squares (error bars represent the standard deviation of the corresponding time series (Piel et al., 2006)). The data from Neumayer (with standard deviation) comprise 22 years of continuous observation $(1983-2005)$

Fig. 11: Overall correlation of MS with nss- $\mathrm{SO}_{4}{ }^{2-}$ concentrations (correlation coefficient $\mathrm{r}=$ $0.72)$.

Fig. 12: Ternary diagram of the $\mathrm{SO}_{4}{ }^{2-}, \mathrm{Na}^{+}$, and $\mathrm{Cl}^{-}$aerosol composition at Kohnen. The data point positions, reflecting the relative composition are normalized such that the composition corresponding to pure seawater sea salt is localized in the centre of the diagram, marked by a star. The diamond marks the composition of totally fractionated sea salt with all sulfate initially precipitated as Mirabilite, while partly depleted sea ice sources sulfate would be located within the hatched area. Measured points are presented as grey circles. The dotted line represents the composition of fractionated sea salt aerosol plus additional nss- $\mathrm{SO}_{4}{ }^{2-}$ and the broken one that of seawater sea salt plus additional nss- $\mathrm{SO}_{4}{ }^{2-}$. 


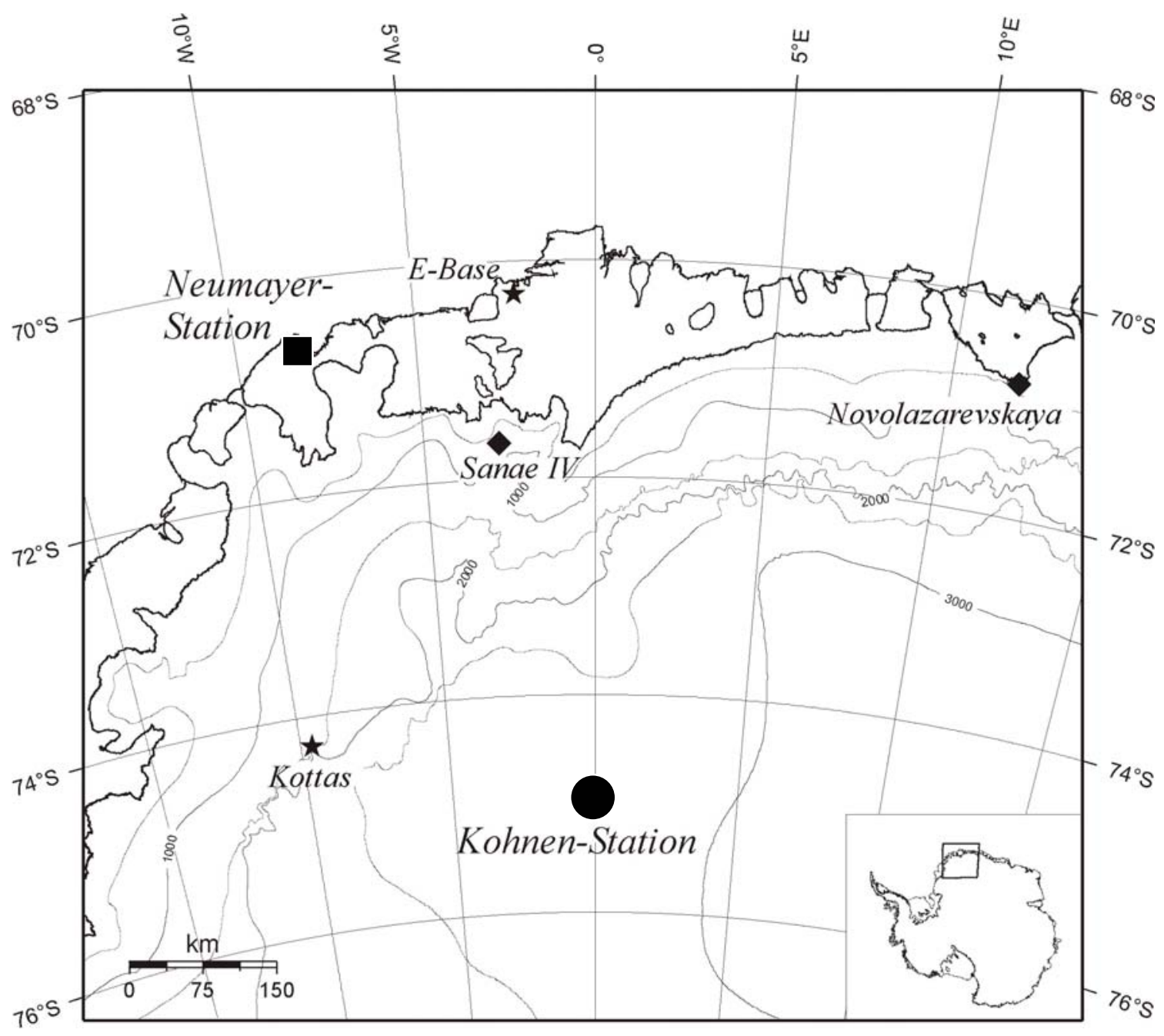

Fig. 1. Geographical position of the EPICA drill site in Dronning Maud Land (Kohnen Station) in relation to the Neumayer over-wintering site. 


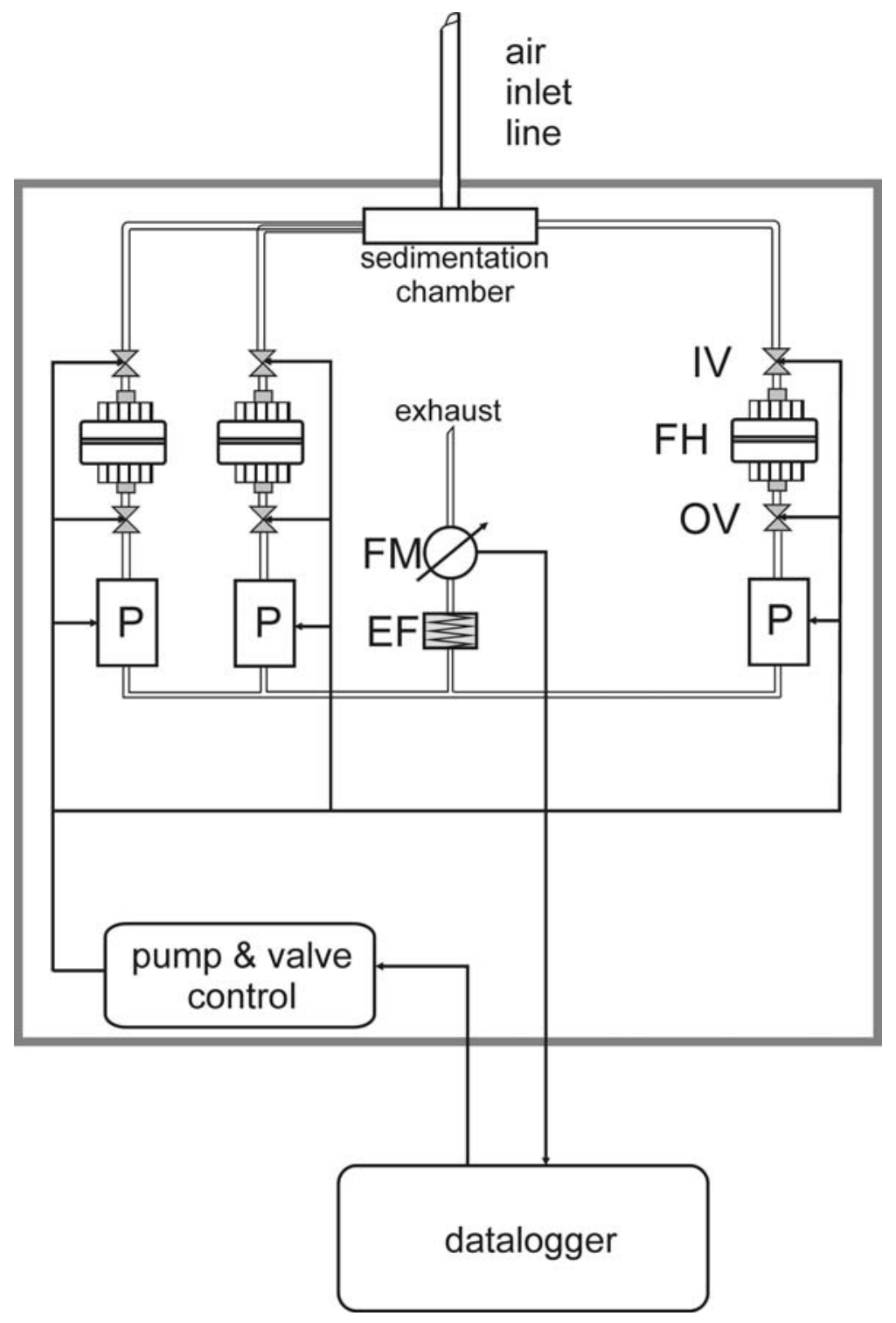

Fig. 2: Diagram of the technical layout of the automated aerosol sampler installed at EDML. Abbreviations: P, carbon vane pumps (22); EF, exhaust filter; FH, filter holders (22); FM, flow meter; IV, inlet valves (22); OV outlet valves (22). To enhance clarity, only 3 out of 22 filter units are shown. 


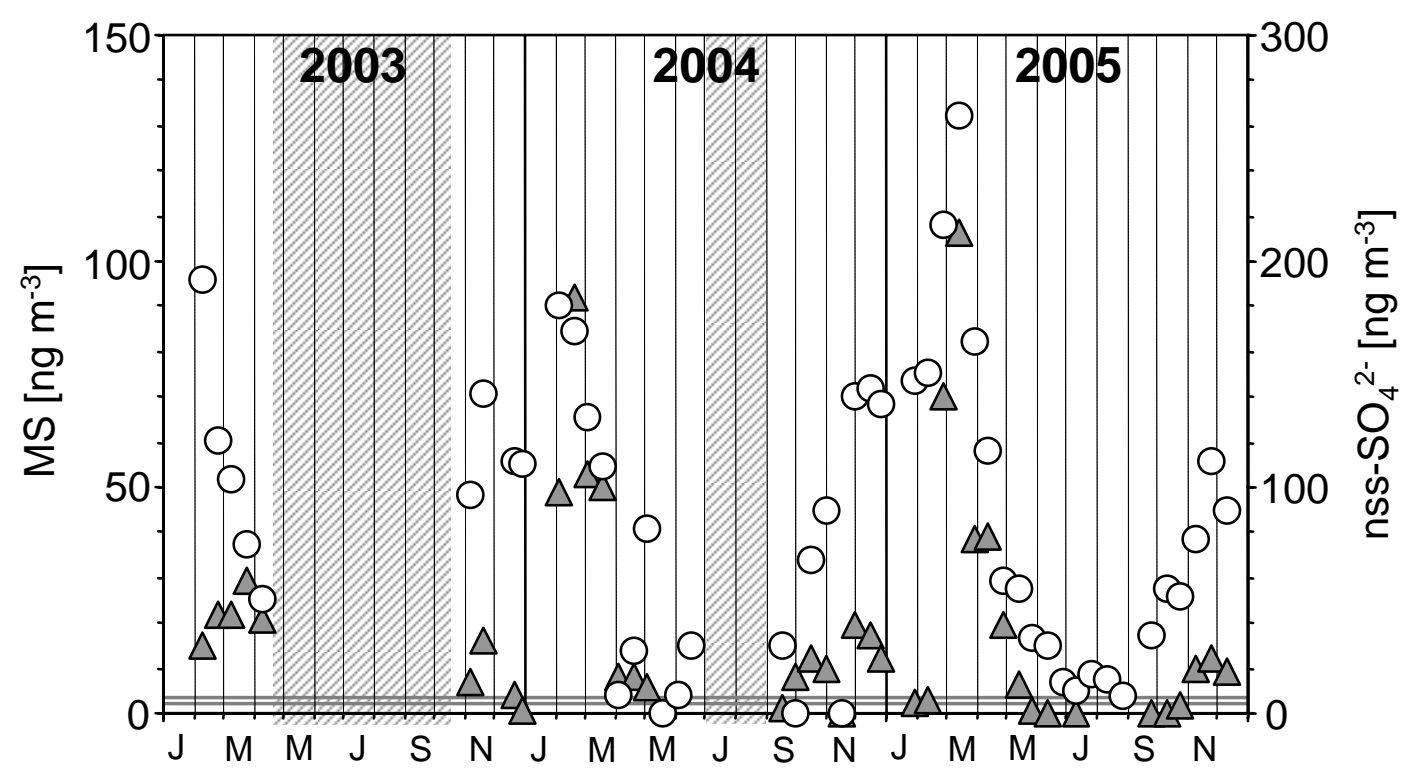

Fig. 3. Concentrations of MS (triangles) and nss- $\mathrm{SO}_{4}{ }^{2-}$ (circles) observed during the years 2003, 2004 and 2005 at Kohnen Station. Hatched areas mark sampler down times due to power failure. Grey bars denote the detection limit for MS (2.7 $\left.\mathrm{ng} \mathrm{m}^{-3}\right)$ and nss-SO ${ }_{4}^{2-}\left(4.5 \mathrm{ng} \mathrm{m}^{-3}\right)$, respectively. 


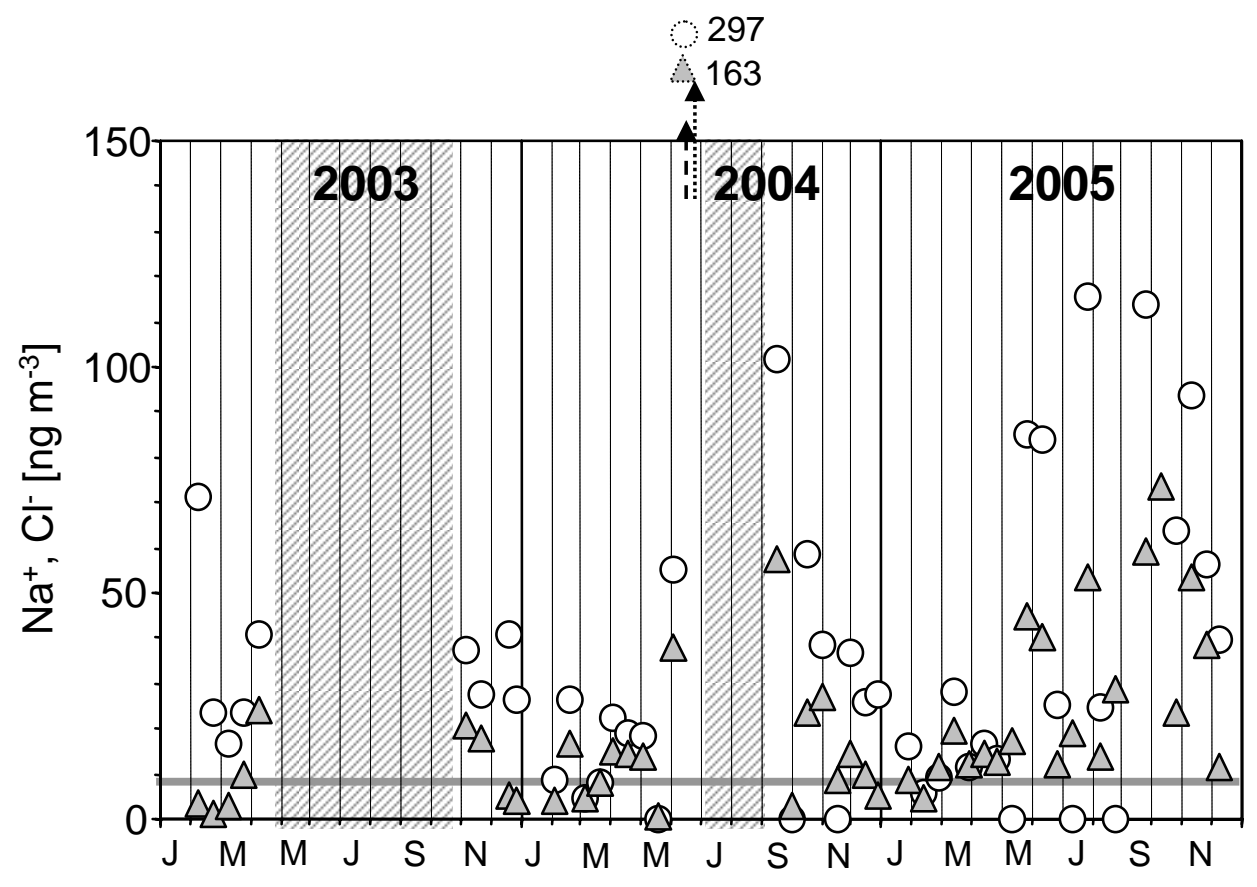

Fig. 4. Same as Fig. 2, but for $\mathrm{Na}^{+}$(triangles) and $\mathrm{Cl}^{-}$(circles). The grey bar marks the $8.9 \mathrm{ng} \mathrm{m}^{-3}$ detection limit for $\mathrm{Cl}^{-}$while that of $\mathrm{Na}^{+}\left(0.28 \mathrm{ng} \mathrm{m}^{-3}\right)$ is not displayed. 


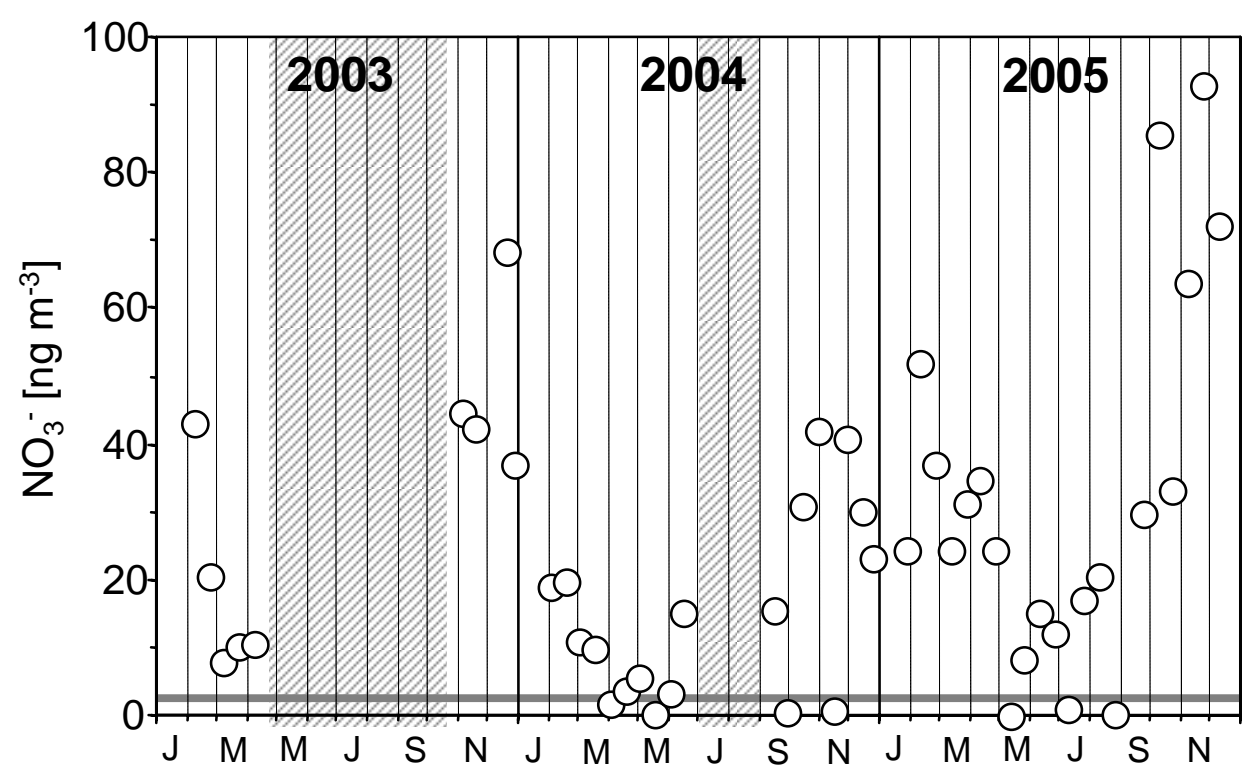

Fig. 5. Same as Fig. 2, but for $\mathrm{NO}_{3}{ }^{-}$with bold line denoting the $2.9 \mathrm{ng} \mathrm{m}^{-3}$ detection limit. 

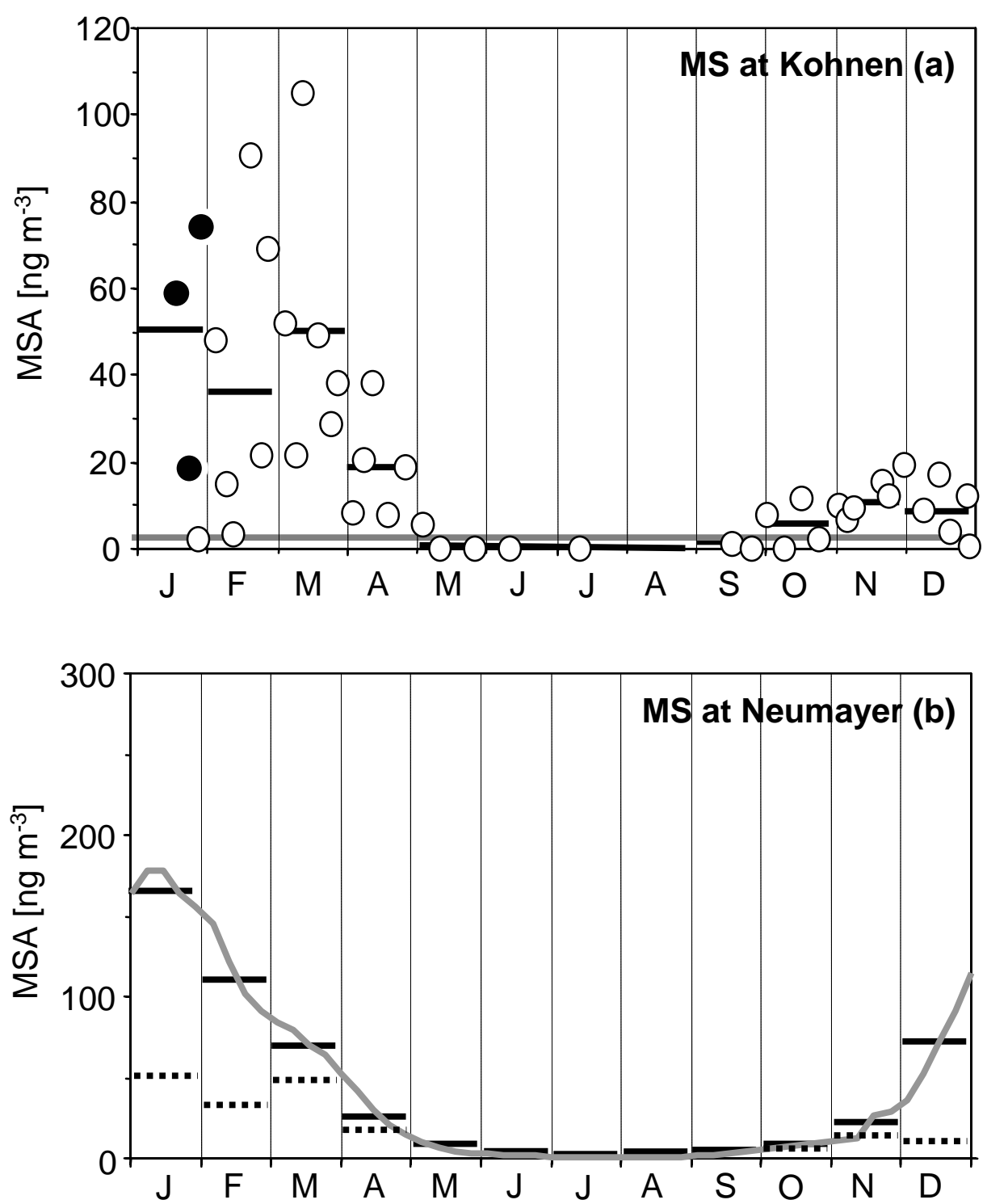

Fig. 6: Seasonal cycles of MS (open circles) at Kohnen (a) during the years 2003 to 2005, including mean results from 2000-2002 summer campaigns (filled circles) contrasted to the mean MS seasonality at Neumayer for the 1983-2005 period (b). Black bars represent monthly means from the corresponding site, dashed bold lines in (b) are again the monthly means from Kohnen. The bold grey line in (a) is the MS detection limit at Kohnen. 

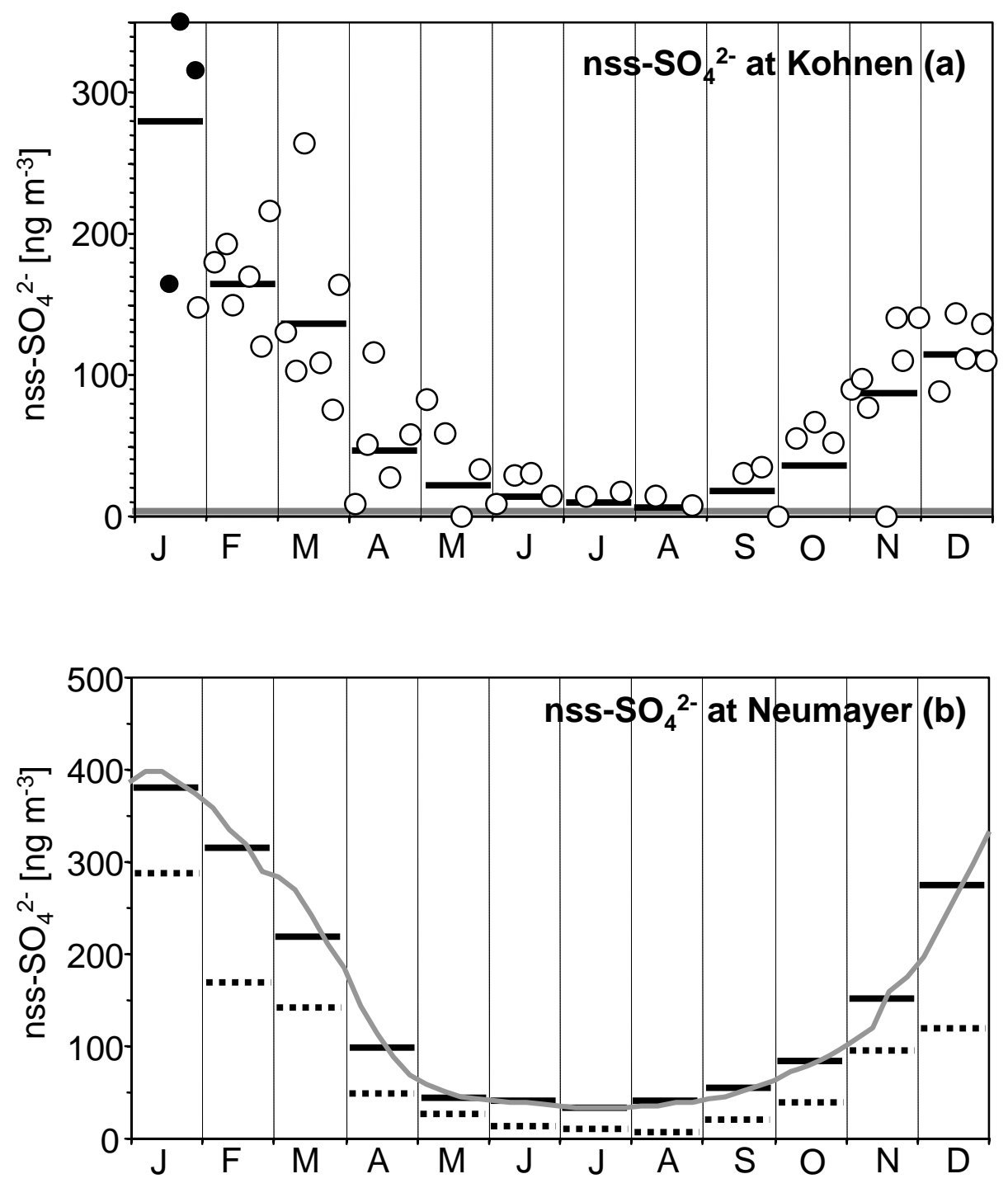

Fig. 7. Same as for Fig. 6, but for nss- $\mathrm{SO}_{4}{ }^{2-}$ concentrations (open circles: automated sampler, filled circles: separate summer campaigns) 

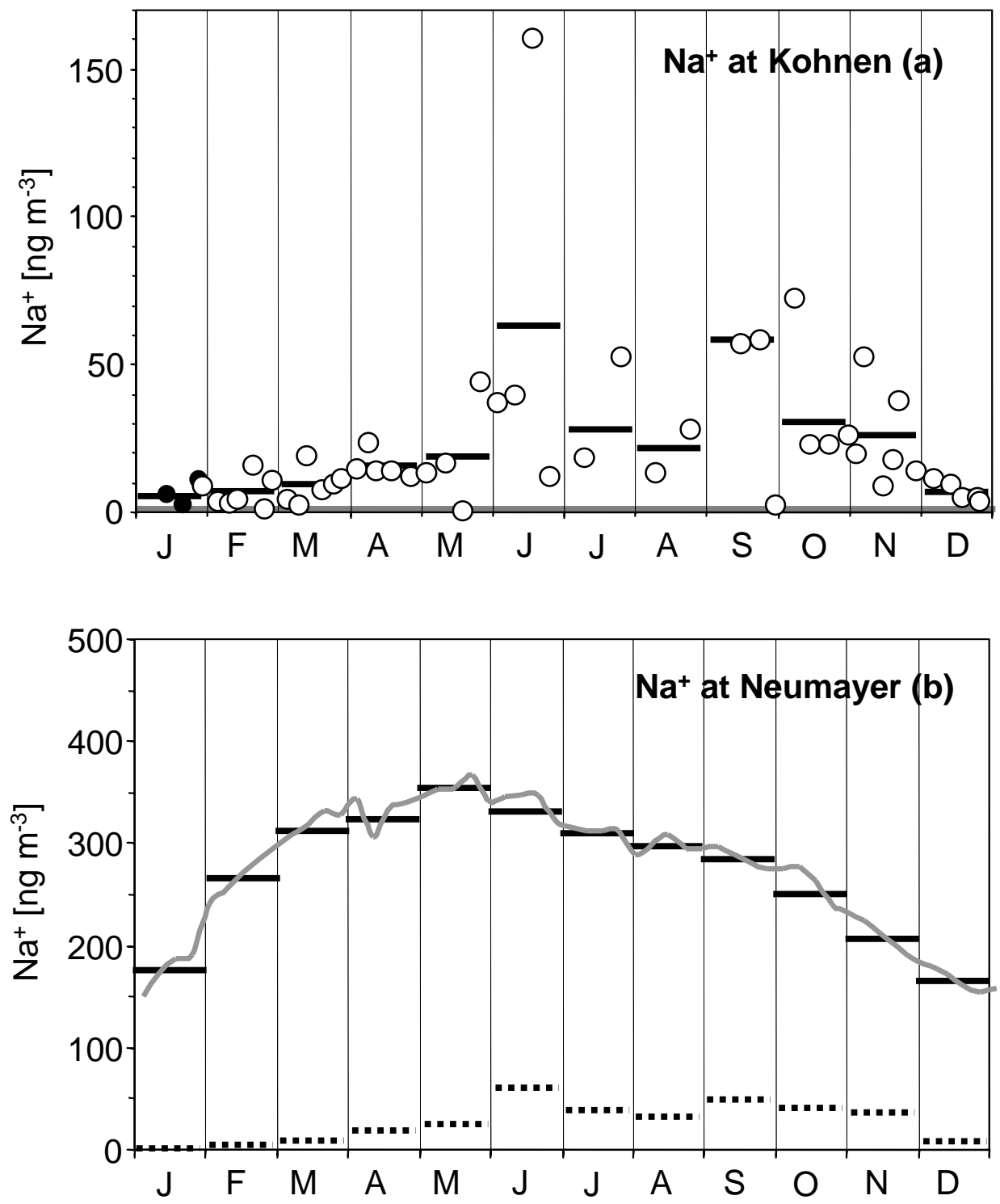

Fig. 8. Same as Fig. 6, but for $\mathrm{Na}^{+}$concentrations (open circles: automated sampler, filled circles: separate summer campaigns). 

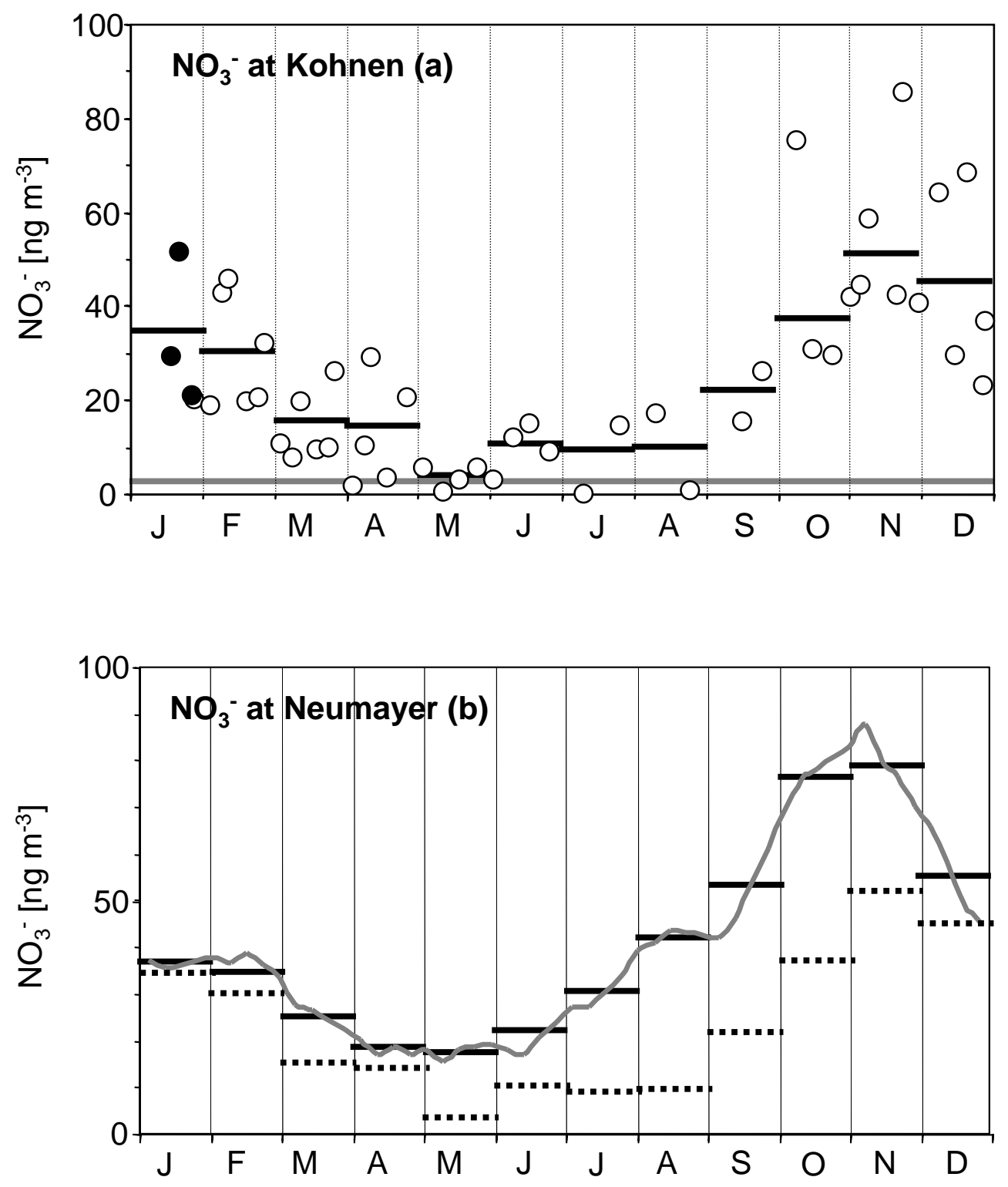

Fig. 9. Same as Fig. 6, but for $\mathrm{NO}_{3}^{-}$concentrations (open circles: automated sampler, filled circles: separate summer campaigns). 


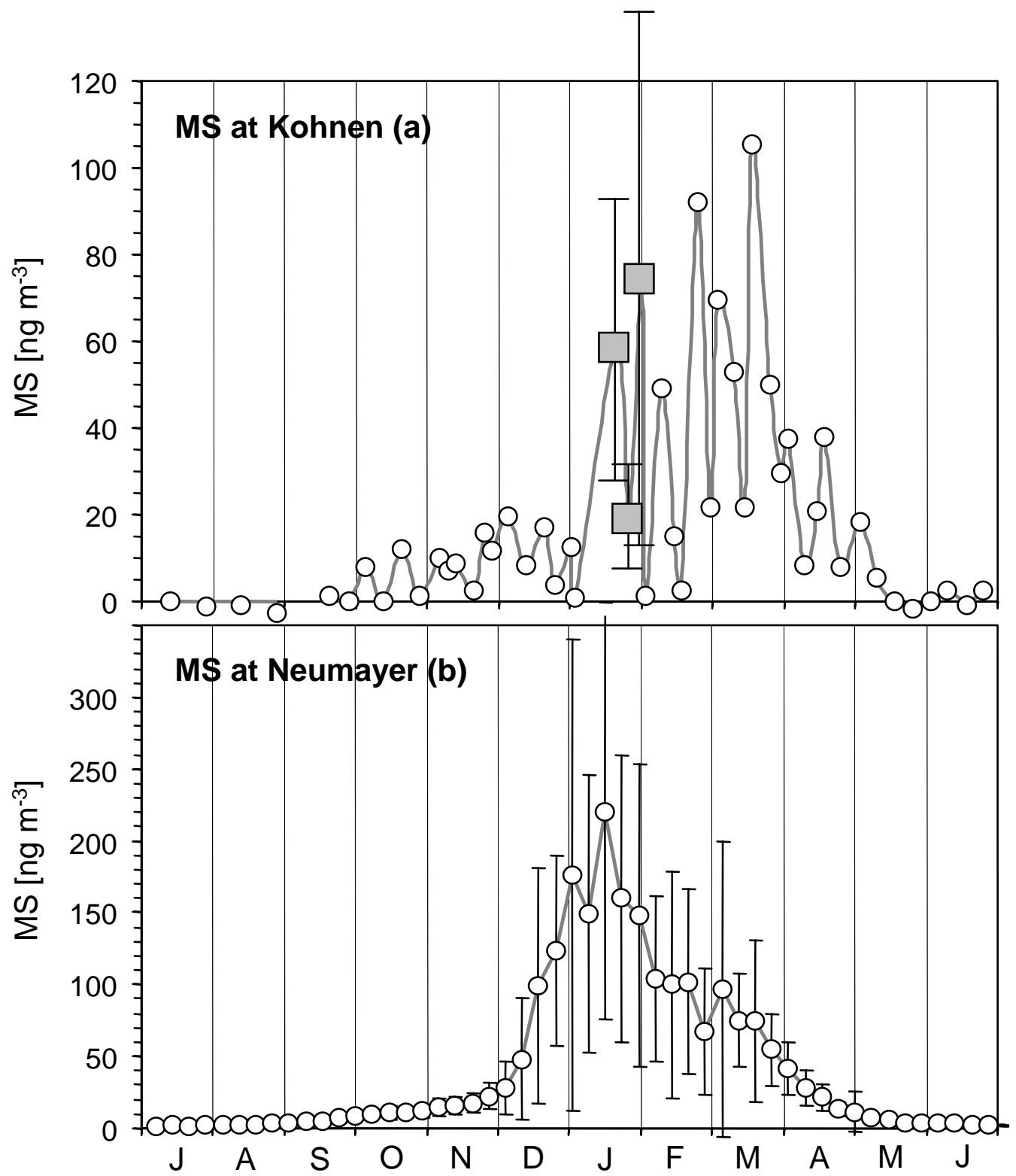

Fig. 10. Mean seasonality of atmospheric MS at Kohnen (a) and Neumayer (b). For Kohnen, the results from three additional summer campaigns were displayed by grey squares (error bars represent the standard deviation of the corresponding time series (Piel et al., 2006)). The data from Neumayer (with standard deviation) comprise 22 years of continuous observation (1983-2005). 


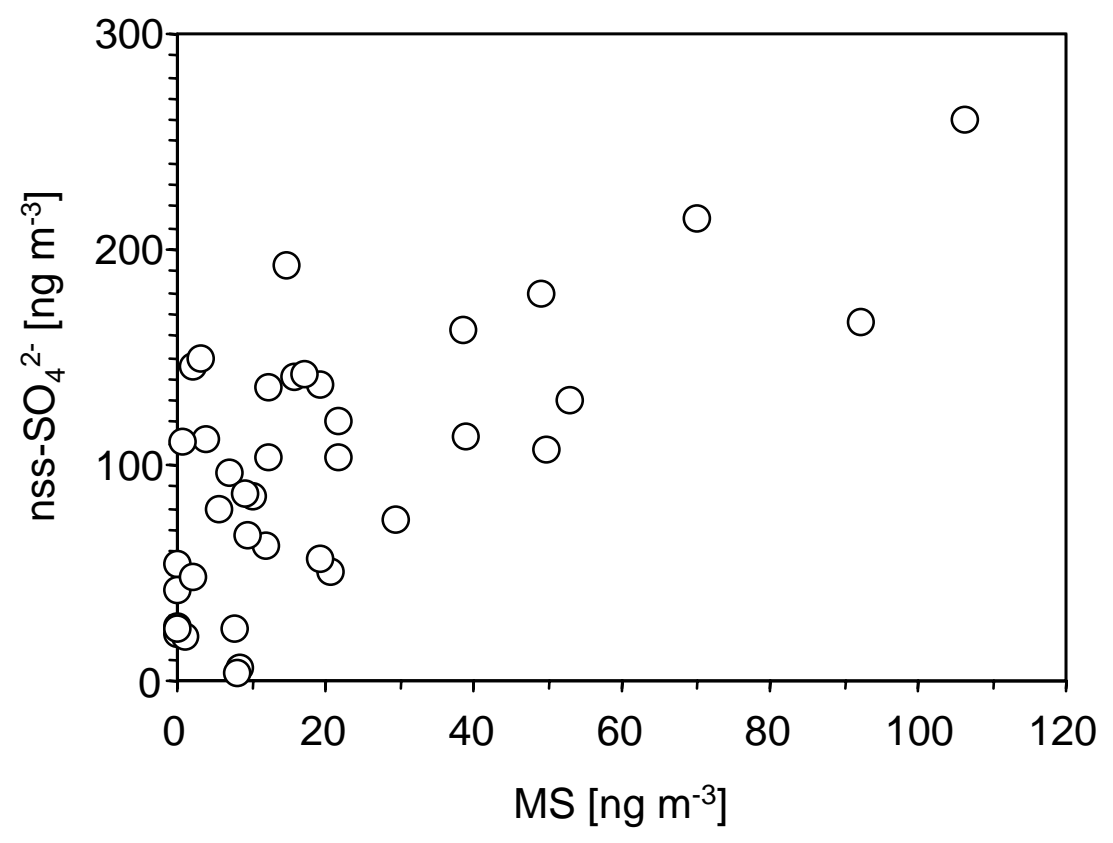

Fig. 11: Overall correlation of $\mathrm{MS}$ with $\mathrm{nss}_{-} \mathrm{SO}_{4}{ }^{2-}$ concentrations (correlation coefficient $r=0.72$ ). 


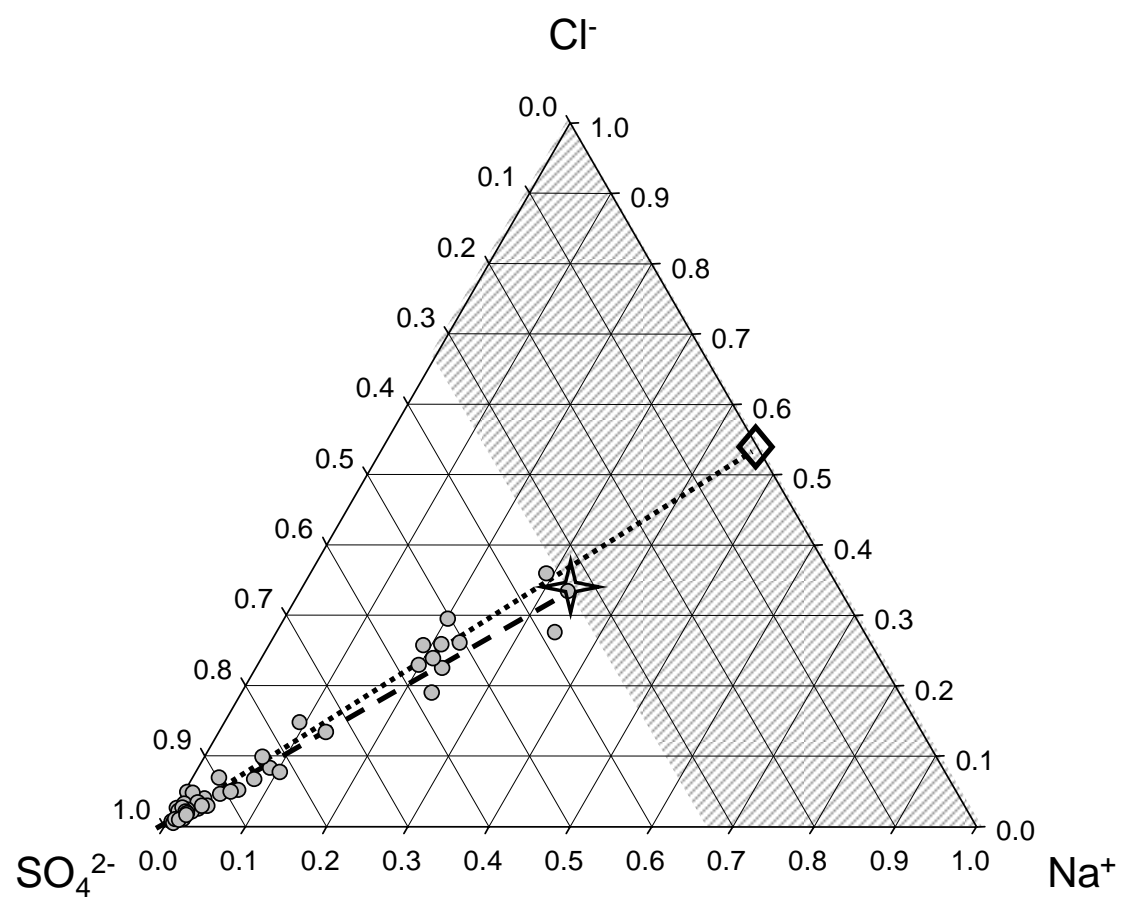

Figure 12: Ternary diagram of the $\mathrm{SO}_{4}^{2-}, \mathrm{Na}^{+}$, and $\mathrm{Cl}^{-}$aerosol composition at Kohnen. The data point positions, reflecting the relative composition are normalized such that the composition corresponding to pure seawater sea salt is localized in the centre of the diagram, marked by a star. The diamond marks the composition of totally fractionated sea salt with all sulfate initially precipitated as Mirabilit, while partly depleted sea ice sources sulfate would be located within the hatched area. Measured points are presented as grey circles. The dotted line represents the composition of fractionated sea salt aerosol plus additional nss- $\mathrm{SO}_{4}{ }^{2-}$ and the broken one that of seawater sea salt plus additional nss- $\mathrm{SO}_{4}{ }^{2-}$. 